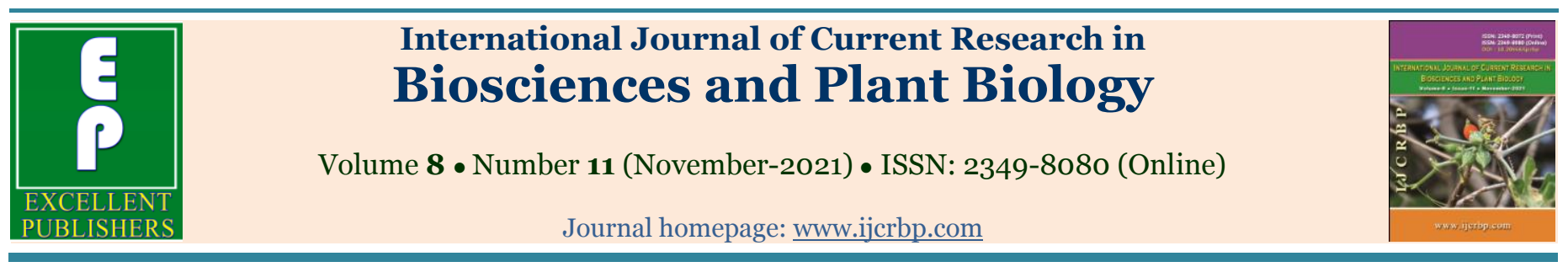

Original Research Article

doi: https://doi.org/10.20546/ijcrbp.2021.811.002

\title{
The influence of periodic fires on the high Guinean savannas and the carbon stock in Cameroon
}

\author{
Pamboundem Ndam Aïchetou ${ }^{1}$, Tchobsala $^{2}$, Oumarou Zéphirin ${ }^{1}$, Dona Adoum ${ }^{1}$, \\ Mapongmetsem Pierre Marie ${ }^{1}$
}

\author{
${ }^{I}$ Department of Biological Sciences, University of Ngaoundéré, PO Box: 454 Ngaoundere, Cameroon \\ ${ }^{2}$ Department of Biological Sciences, University of Maroua, PO Box: 644 Maroua, Cameroon
}

*Corresponding author; e-mail: pamboundemndamaicha@gmail.com, (+237) 697106973

\section{Article Info}

Keywords:

Carbon

Fires

High Guinean savannas

Woody cover

Abstract

The influence of periodic fires in the high Guinean savannas of Cameroon on woody plants and carbon stock is poorly documented. To fill this gap, work was carried out in the high Guinean savannas of Cameroon with the aim of contributing to the assessment of the effects of periodic fires on the woody cover and the carbon stock. The methodology used consists of carrying out semistructured household surveys and floristic inventories in the Arrondissement of Ngaoundéré III and Ngan'ha, in the Department of Vina. A total of 50 households were interviewed at a rate of 25 per Borough according to a questionnaire prepared beforehand. For the botanical inventories, 02 types of savannah were selected: regularly burnt savannas (shrub savannas, wooded savannas) and those not burned for at least 10 years (shrub savannas, tree savannas). The choice of control savannas was made according to the indications of the peasants. In each of them, the $1 \mathrm{~km} \times 20 \mathrm{~m}$ transects were covered and the diameter at breast height (dbh) of the woody plants was measured using a dbh meter at $1.3 \mathrm{~m}$ from the ground for large trees. and at 30 or $50 \mathrm{~cm}$ from the ground for shrubs and shrubs. The results show that climate change is palpable in the area. The rains are increasingly rare, the drought has become severe and the agricultural calendar is no longer respected. The specific diversity has become relatively low with 51 species having been inventoried, divided into 46 genera and 23 families. Savannahs that are not burnt produce more biomass than those that are burnt. The perfect illustration is given by the non-burnt tree savannah of Ngaoundere III with an above-ground and root biomass of $102.23 \mathrm{t} / \mathrm{ha}$ and $20.70 \mathrm{t} / \mathrm{ha}$ respectively. Annona senegalensis (1.27 tC / ha) is the species contributing massively to carbon sequestration in the high savannas of the Vina. Thus, by acting on the availability of plant biomass, fires contribute to the erosion of biodiversity. Adequate measures are urgently needed to limit bushfires.
\end{abstract}

- Received: 27 December 2020 • Revised: 26 May 2021 • Accepted: 1 August 2021 • Published Online: 6 November 2021 


\section{Introduction}

The risks linked to global warming affect every continent and affect all sectors of the economic and social life of populations (Mbow, 2009). In the implementation of the United Nations Framework Convention on Climate Change, Africa is counted among the areas where natural vegetation can contribute to carbon emissions through degradation processes (bush fires, deforestation, erosion); or sequestration if activities are carried out in terms of reforestation and reconstitution of degraded lands. In climate change mitigation, fires are blamed for their contribution of 13 to $40 \%$ to global greenhouse gas (GHG) emissions in atmospheric carbon equivalent (Bowman and Wilson, 1995). The climatic scenarios predict that, for a global temperature increase of $4^{\circ} \mathrm{C}$ by 2080 , the consequence would be an increase in the length of the dry season and fire factors by $30 \%$ and a doubling of the areas burned (Koffi et al., 1995). Of the 7 Gt of GHGs emitted per year, $3.4 \mathrm{Gt}$ come from the forestry sector, including 1.1 Gt from fires and bush fires (IPCC, 2007). Due to its setbacks, fire can thus threaten the living environment, health and safety of people and property (Vieira et al., 2015). Especially uncontrolled fires can also induce a loss of plant biomass (Sawadogo, 211). The frequency of fires limits, on the one hand, the regeneration of woody species whose seed strands and plantlets are destroyed and, on the other hand, the height growth of woody species, these two actions having a significant impact on the dynamism of vegetation and its progression towards climax (IPCC, 2007). In tropical savannas in particular, iterative fires have been shown to have a detrimental influence on the sustainability of ecological resources and services (Sawadogo, 2011). This perception has led to special attention to the carbon sequestration capacities of tropical forests and savannas in Africa (UNFCCC, 2015). The high Guinean savannas of the Adamawa, periodically covered by fires, constitute ecosystems with fragile ecology. These fires represent a key factor in the loss of the biological diversity of these ecosystems.

In Cameroon, the ecological interest in climate change has given rise to a great deal of research aimed at better understanding its origins and the mechanisms of evolution. In forest (Kotto-Samé et al., 1997; Zapfack, 1998; Zapfack et al., 2005) and northern (Ibrahima and Abib, 2008; Tchobsala et al., 2014; Kemeuze et al., 2015), the works carried out on carbon stocks are legion. However, none of this work has addressed the influence of fires on productivity, the carbon stock in the savannas; however, they act on the productivity of savannas and play a determining role in their development. The UNFCCC, through the Clean Development Mechanisms (CDM) of the Kyoto Protocol has in recent years, aroused great enthusiasm among developing countries that see it as an opportunity to improve the environment through an increase in forest areas. While benefiting from carbon credits set up through international financial instruments (Mbow, 2009). The effects of fire on the savannah have given rise to a large number of studies (Bane-Ena, 2007; Diop, 2007; Bond and Parr, 2010; Kwon et al., 2013; Kamau and Medley, 2014). However, little is known about its consequences on carbon sequestration. The aforementioned gaps motivate and justify this work, which aims to contribute to the assessment of the effects of fires on the woody cover and the carbon stock in the high Guinean savannas of Ngaoundéré.

\section{Materials and methods}

\section{Presentation of the study area}

The study took place in the districts of Ngaoundéré III and Ngan $\mathrm{Ha}$ in the Department of Vina located between latitude $7^{\circ} 37^{\prime} \mathrm{N}$ and longitude $13^{\circ} 34^{\prime} \mathrm{E}$. In each arrondissement, two types of savannah were chosen according to the guidelines of the local population. These are regularly burnt shrub savannas and regularly burnt woodland savannas, while the control savannas are those that have not been affected by fires for at least 10 years. Information on the age of the non-burnt savannas was provided on site by the populations of the various districts chosen.

\section{Methodology}

\section{Socio-economic surveys}

Semi-structured interviews were carried out with 100 people, at a rate of 50 per district, using a previously prepared questionnaire. In each arrondissement 05 villages were chosen. The questionnaire consisted of open questions, closed questions and leading questions. For closed questions, the respondent reacts with yes or no, unlike open questions where he expresses himself freely. Regarding the oriented questions, several answers are proposed and the respondent chooses one or more. The main topics covered relate to fires, climate change (causes, manifestations, and endogenous solutions), biodiversity, deforestation, etc. 


\section{Floristic inventories}

The floristic inventories were carried out in the shrub and wooded savannahs affected by fires or not in the villages mentioned above. In each type of savannah, transects $1 \mathrm{~km}$ long and $20 \mathrm{~m}$ wide were installed to inventory the flora. A total of 100 transects were carried out, ie an area of 30 ha. All woody species were systematically counted. All the woody plants of diameter at breast height $(\mathrm{dbh} \geq 2.5 \mathrm{~cm}$ and height $>2 \mathrm{~m}$ were systematically counted and measured. Reference botanical documents (Arbonnier, 2008; Souane, 1997) were used for the identification of species in situ for unidentified species, herbarium samples were collected for subsequent identification at the Biodiversity and Sustainable Development Laboratory of the University of Ngaoundéré or at the National Herbarium of Cameroon in Yaoundé. Thus, the diameter at breast height (dbh) of woody plants was measured using a dhp-meter at $1.3 \mathrm{~m}$ from the ground for large trees and at 30 or $50 \mathrm{~cm}$ from the ground for shrubs and shrubs. were injured in the bands delimited by the strings so as not to be counted twice. For the boundary trees, those located on the right edge were taken into account in the direction of advance in the transects. The experimental device explored is a Split -plot to four repetitions.

\section{Vegetation carbon stock}

\section{Aerial and root phytomass of vegetation}

The non-destructive method was used for the estimation of biomass in this work. It is based on databases on timber volumes and takes into account the Dhp, the specific density of the timber (Chave et al., 2005). The equation of Chave et al. (2005) takes into account individuals of smaller diameters $(5 \leq$ Dhp $\leq 156 \mathrm{~cm})$ and rainfall between (1500-4000 $\mathrm{mm} /$ year). The aboveground phytomass is: AGB $=\alpha \operatorname{Exp}[-1.499+$ $2.148 * \ln (\mathrm{DBH})+0.207 *(\ln (\mathrm{DBH}) 2-0.0281 *(\ln$ (DBH)) 3]. AGB is the aboveground biomass (in $\mathrm{kg}$ ); Dbh is the diameter $(\mathrm{cm})$ at $1.30 \mathrm{~m}$ above the ground and $\alpha$ is the specific density of wood.

Root biomass was estimated using the relationship developed by Cairns et al. (1997): $\mathrm{Br}=\exp (-1.0587+$ $0.8836 \mathrm{x} \ln (\mathrm{Ba}))$, with $\mathrm{Br}=$ root biomass, $\ln =$ Natural logarithm and $\mathrm{Ba}=$ above-ground biomass.

To determine the final biomass values, aboveground biomass was added to the biomass of the roots below the soil surface $(\mathrm{Bt}=\mathrm{Ba}+\mathrm{Br})$ with $\mathrm{Bt}=$ total biomass, $\mathrm{Br}=$ root biomass and $\mathrm{Ba}=$ aboveground biomass (FAO, 1997).

From this biomass, the quantity of carbon ( $\mathrm{Kg} / \mathrm{ha}$ ) was obtained by multiplying this biomass by a conversion factor of $50 \%$.

\section{Result analysis}

For the analyses of the results, Excel 2016 was used for the plots of the histograms, the calculations of the means. Stat-graphics Plus 5.0 Software was used for the ANOVA testing.

\section{Results and discussion}

\section{Peasant perception of the environment of the high Guinean savannas}

The perception of the populations on climate change in the high Guinean savannas varies according to the people. In the Vina and mainly in the Arrondissement of Ngan'Ha, the populations state that the rainfall was particularly abundant in the years 2002, 2004, 2009 and 2016 (Fig. 1). During these years, the peasants obtained low agricultural yields and a destruction of the vegetation orchestrated by the unprecedented floods.

The analysis of precipitation and temperatures recorded in the meteorological station of Ngaoundéré-airport over a period of 30 years, obtained in 2018 more or less confirms the farmers' statements. The peaks of precipitation are in 2001 (104.76 mm), 2004 (109.76 $\mathrm{mm}), 2009(136.36 \mathrm{~mm})$ and $2016(145.45 \mathrm{~mm})$. In the high Guinean savannas, the incidences of temperature increase very often combine with the decrease in precipitation. These results are in agreement with those of Mamah et al. (2019) in the ecological zone of the high Guinean savannas of Cameroon.

In general, the surveys on rainfall obtained from the population are more or less in line with the high rainfall recorded by ASECNA in 2008, 2010, 2012 and 2016. This variation in rainfall could lead to a disruption of the vegetation development cycle. Insufficient trees would cause considerable lack of precipitation in a given area (Basnet, 2009; Alalade et al., 2019). Populations report certain natural phenomena (decrease in rainfall) as the cause of climatic variability in the high Guinean savannas of Adamawa. IPCC (2002) 
found similar results by showing that natural internal processes (internal variability), or anthropogenic or natural external variations (external variability) could cause climate variability. According to the populations surveyed, bush fires and logging could be among the first factors of climate change. In the sense that some authors assert that deforestation thus has an impact on local and immediate climatic variability (Loreau, 2001; Diaz, 2001). Localleti (1993) also reports that massive deforestation in the tropics can radically transform the overall tropical planetary circulation, water balance and rainfall regime.
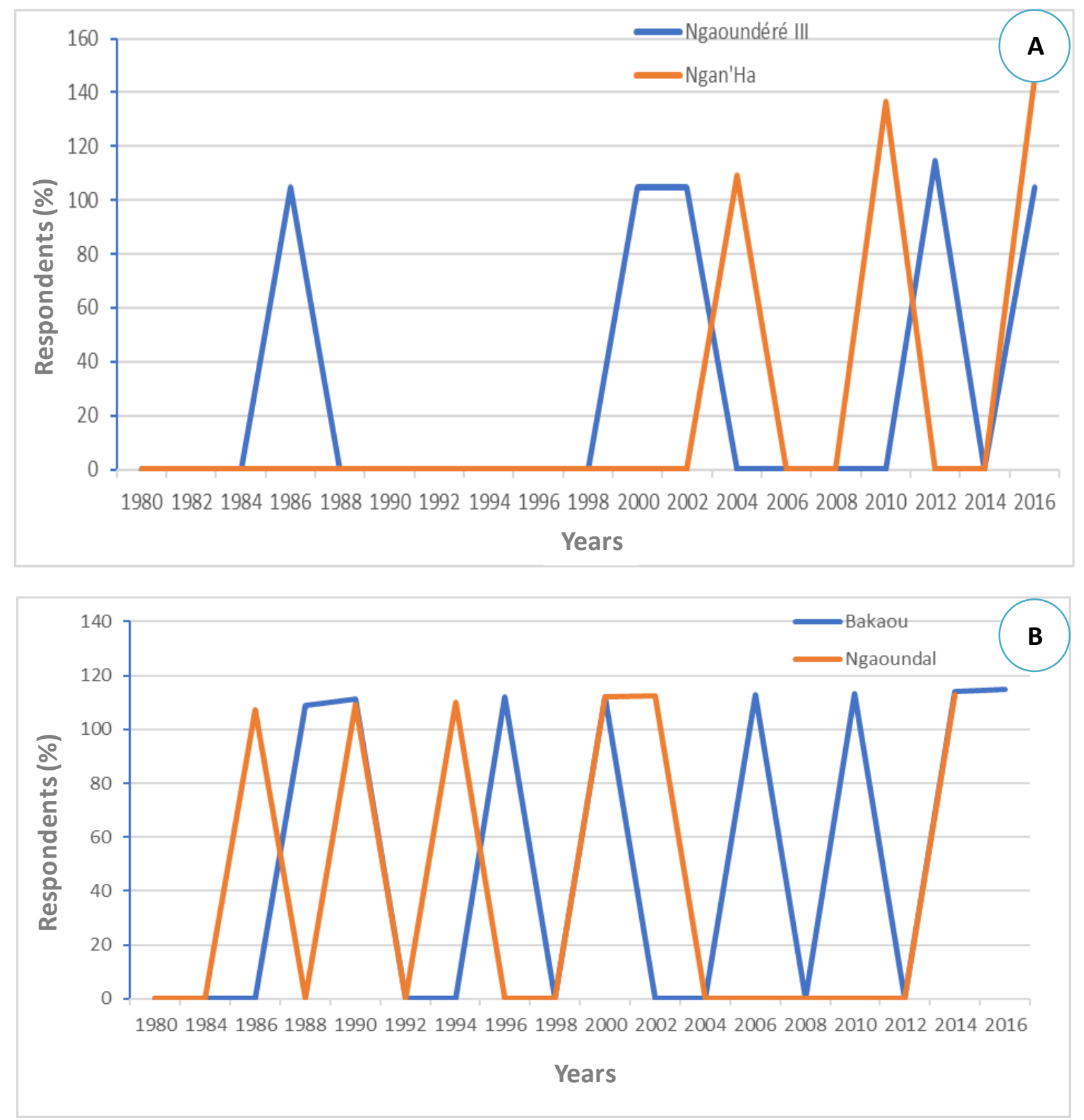

Fig. 1: Population perception of rainfall (a) and rainfall trend (b) in the Vina.

\section{Causes of climate change}

The main causes of climate change according to the populations are among others the excessive cutting of trees, periodic bush fires, the cutting of trees associated with bush fires, agriculture, breeding, and then the cutting of trees associated with breeding (Fig. 2). In the Ngaoundéré III site, bush fires $(42.85 \%)$ are among the factors responsible for climate change. Some of these factors are related. This is the case of the cutting of 
trees coupled with breeding, then the cutting of trees associated with fires, according to the populations. These anthropogenic activities accelerate the degradation of vegetation. Culturally and socially, some people believe that climate change is the result of disregarding social prohibitions like the destruction of sacred forests. Currently, the populations are no longer discerning because the sacred forests which were true sanctuaries are destroyed or set on fire. However, they are prohibited to the uninitiated. This statement is in line with that of authors like Ishaya et al. (2018) in Nigeria. Some of these activities, such as cutting trees, breeding or a combination of the two, are more accentuated in the Ngaoundéré III site. The results of surveys carried out among populations are in agreement with those of other authors concerning the causes of climate change (Tchobsala, 2011; Afelu et al., 2016). Deforestation also has a local and immediate climatic impact (Loreau, 2001; Diaz, 2001). These impacts could therefore lead to major upheavals of ecosystems (Ducroux and Jean, 2004). Climate variability can be due to anthropogenic or natural variations (external variability) (IPCC, 2002). Bush fires are among the most important external factors in triggering climate change. They cause the loss of certain plant species after their passage and greenhouse gases. Climate change will modify ecosystems and human populations would obviously be affected with all the negative consequences that this could cause. The populations are aware of the negative effects of fires on the woody cover. Ecosystems can be disturbed, thus causing the disruption of ecosystems (Ducroux and Jean, 2004).

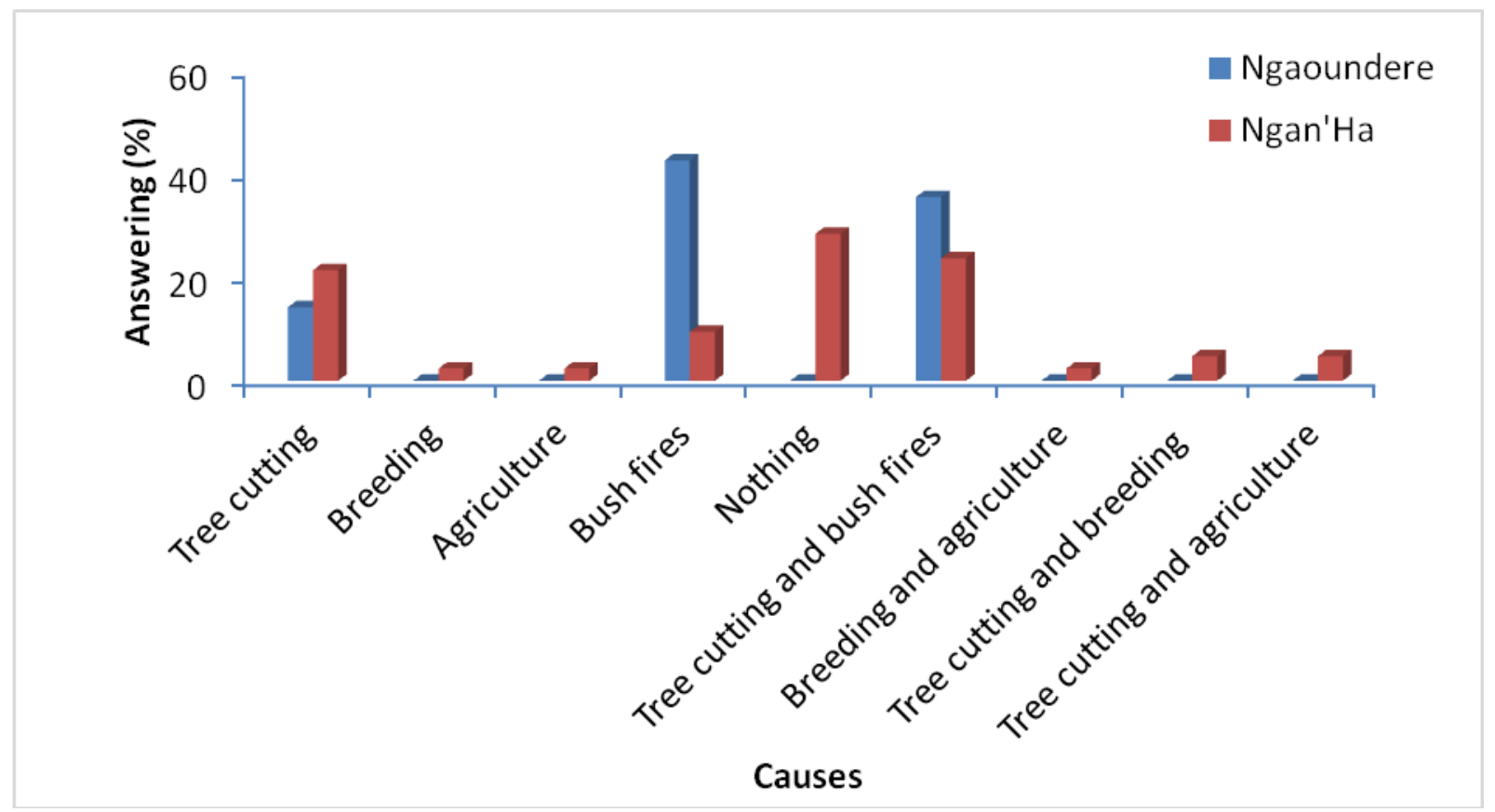

Fig. 2: Main causes of climate change.

\section{Endogenous climate change mitigation strategies}

Faced with climatic fluctuations, the population of the high Guinean savannas of Adamaoua adopts adaptation and mitigation strategies. Thus, they increasingly implement the cultivation and protection of trees in fields and around homes. The main endogenous knowledge developed for the adaptation and mitigation of climate change in the Department of Vina are awareness raising on the protection of savannas (setting up of vigilance committees), the use of organic fertilizers (compost, manure ...) Instead of chemical fertilizers, planting trees, setting up plant fences to surround the concession and / or the fields. Similar results are reported by Mamah et al. (2019) in Borassus aethiopum agroforestry parks in Cameroon.

\section{Floristic richness of the high Guinean savannas}

A total of 51 species were inventoried, divided into 46 genera and 23 families. The number of taxa varies from one Arrondissement to another and also from one plant formation to another. The analysis of variance shows an absence of homogeneity between individuals, genera and families of each plant formation $(0.0001<0.001)$. The species of the different plant formations are 
different $(0.000<0.001)$. The witness sites have a higher biodiversity than that of the regularly burnt plant formations. The number of species listed is low compared to that of Tchobsala (2011) who inventoried
77 species and 66 species respectively in the shrub and tree savannas of Ngaoundéré. The action of fire in the savannah limits the progressive development of forest vegetation (Rippstein, 1985).

Table 1. Floristic diversity of the Guinean savannas.

\begin{tabular}{|c|c|c|c|c|c|c|c|c|c|c|c|c|c|}
\hline \multirow{2}{*}{ Districts } & \multicolumn{2}{|l|}{ BSS } & \multicolumn{4}{|c|}{ BTS } & & \multicolumn{2}{|c|}{ SSW } & \multicolumn{3}{|c|}{ TSW } & \multirow[b]{2}{*}{ NF } \\
\hline & NI & NS & NG & NF & NS & NG & NF & NS & NG & NF & NS & NG & \\
\hline Ngaoundere III & 4158 & 29 & 23 & 17 & 25 & 22 & 16 & 26 & 24 & 20 & 28 & 26 & 21 \\
\hline Ngan'Ha & 5051 & 30 & 27 & 18 & 25 & 21 & 18 & 23 & 21 & 19 & 30 & 29 & 24 \\
\hline
\end{tabular}

BSS: burnt shrub savanna, BTS: burnt tree savanna, SSW: shrub savanna witness, TSW: tree savanna witness, NI: number of individuals, NS: number of species, NG: number of genus, NF: number of families

\section{Floristic diversity of the high Guinean savannas}

Table 2 presents the values of the Shannon, Equitability of Pielou, Simpson indices and the specific quotient of the woody species of the high Guinean savannas. These indices vary according to the sites and the plant formations. The Shannon index ranges from 2.28 bits in regularly burnt shrub savanna (Ngaoundéré III) to 3.28 bits in non-burnt tree savannas (Ngaoundéré III). Piélou's fairness oscillates between 0.29 bits in shrub savannas and 0.96 bits in tree savannas. As for the values of the Simpson diversity index (D), they vary from 0.008 bits in the control tree savanna (Ngan 'Ha) to 0.19 bits in the bush savannah (Ngaoundéré III). In addition, the evidence of shrub savannas is the richest in biodiversity in all of the departments. This situation shows the negative impact of bush fires on plant formations. In general, it appears that the Shannon index in the control savannas is greater than 3. Such a result suggests that these protected savannas are more diverse than those which are regularly burnt. Similar results are reported in the Chadian savannas (Dona et al., 2016).

Table 2: Diversity indices in the Guinean savannas.

\begin{tabular}{lllllllll}
\hline Indices & \multicolumn{2}{l}{ Ngaoundéré III } & & \multicolumn{2}{c}{ Ngan'Ha } \\
& BSS & BTS & SSW & TSW & BSS & BTS & SSW & TSW \\
\hline Shannon & 2.28 & 2.69 & 3.157 & 3.28 & 2.598 & 2.31 & 3.14 & 3.065 \\
Equitability of Pielou & 0.29 & 0.79 & 0.909 & 0.96 & 0.77 & 0.66 & 0.898 & 0.878 \\
Simpson & 0.19 & 0.12 & 0.057 & 0.05 & 0.11 & 0.15 & 0.055 & 0.008 \\
specific quotient & 1.26 & 1.14 & 1.08 & 1.08 & 1.11 & 1.19 & 1.10 & 1.03 \\
\hline
\end{tabular}

BSS: burnt shrub savanna, BTS: burnt tree savanna, SSW: shrub savanna witness, TSW: tree savanna witness.

\section{Structure of the vegetation of the high Guinean savannas}

\section{Diametric distribution of species}

The various plant formations are dominated by woody species with a diameter at breast height ranging from $<0.15 \mathrm{~m}$ to $1.30 \mathrm{~m}$. From diameters $15-30 \mathrm{~cm}$, the numbers decrease sharply as the diameter increases beyond $60 \mathrm{~cm}$ where very few stems are observed. This result suggests the domination of the Guinean savannas by shrubs and the vulnerability of this formation to fires and other degradation actions. Regarding the diameter at breast height (Dbh) of species in plant formations, control shrub savannas show high numbers in all intervals except those of $<0.15$ [. In the control tree savannas which are less disturbed, the closing of the tops of the emergent prevents the development of young regenerations.

The appearance of the histograms in shrub savannas follows an " $\mathrm{L}$ " distribution. This result is in agreement with that of Mapongmetsem et al. (2011) in the high Guinean savannas. This appearance suggests that the regeneration of species of shrub savannahs and control tree savannas is satisfactory and that the maintenance of adult trees is difficult. The species of tree savannas that are periodically burnt no longer have the anatomorphological structures capable of dedifferentiation. This result indicates that a small number of individuals have a Dhp greater than 1.30 meters in regularly burnt plant formations (Fig. 3). Thus, some researchers claim that bush fires are a real cause of disturbance of savannas (Jakko et al., 2000). 


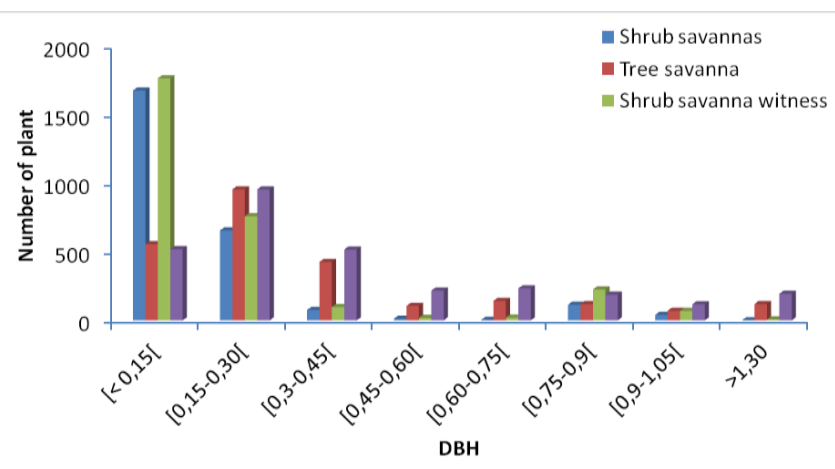

Fig. 3: Diameters at breast height of trees in vegetation.

\section{Vertical distribution of trees in the high Guinean savannas}

Fig. 4 shows the vertical structure of plant formations in the study sites according to height classes. In general, individuals with a height greater than 0.5 meter are in the majority. The number of trees decreases from low height classes $(<0.5 \mathrm{~m})$ to large classes $(>5 \mathrm{~m})$ (Fig. 4). Trees with a height of less than 0.5 meters are the majority. On the other hand, those in the interval [3.5 4] are the least numerous. Overall, this vertical structure sufficiently shows that the least represented stems are the adult stems, except in shrub savannas. The exception in shrub savannas would be justified by the incentive factors (cuts, fires, etc.) of the rejections. Violent fires cause a considerable drop in the successive dynamics as shown by Monnier (1973) in the comparison of the types of vegetation established in the plots of late fires and those of early fires. Notwithstanding the fact that savanna species are generally dwarf, repeated periodic savanna fires contribute to tree size reduction.

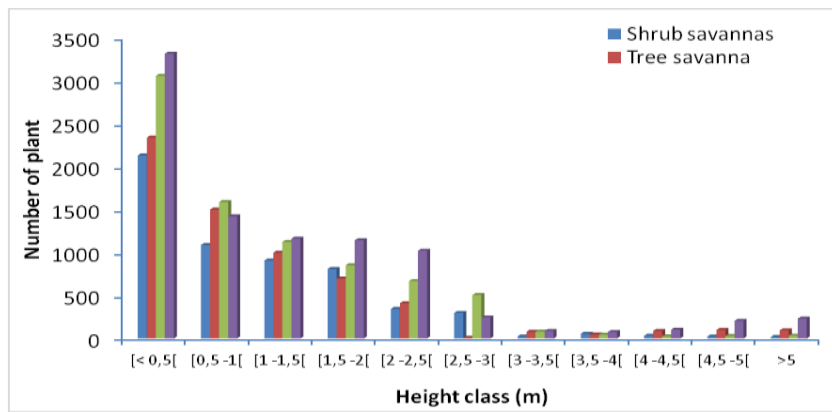

Fig. 4: Distribution of trees by height class.

\section{Epigeal phytomass of the Guinean savannas}

The production of biomass is not identical in the different plant formations studied. The disparities noted are only apparent since the analysis of variance does not indicate any statistically significant difference between the variables noted $(0.224>0.05)$. It should also be noted that unburned savannas (102.23 t/ ha) accumulate more biomass compared to burnt savannas (71.69 $\mathrm{t} / \mathrm{ha})$. The action of fire on plant biomass is similar to the mechanical action of cutting with the biomass being exported out of the mown plot and verifies the hypothesis that fires contribute to the loss of plant biomass. This characterization of the mode of action of fires is consistent with the results of some previous work (Poilecot and Loua, 2009).

To better understand the potential of these wooded savannas in the biomass concentration, this analysis shows us that wooded savannas sequester more carbon than shrub savannas. The strong phytomass is recorded in the wooded savannah. The perfect illustration is given by the wooded savannah of Ngaoundéré III $(102.23 \mathrm{t} / \mathrm{ha})$. Large trees in wooded savannas are more resistant to bush fires. However, similar observations are reported by Joosten et al. (2004). Whether, in shrub savannahs or in tree savannas, the results of this work are weak compared to those obtained by other researchers who have worked on similar issues in other countries (Joosten et al., 2004 and Mbow, 2009).

The root production obtained in the different plant formations is $420.90 \mathrm{t} / \mathrm{ha}$. This biomass value is higher than that of Dona (2018) in the Tandjilé-Est region in Chad. He obtained $314.90 \mathrm{t} / \mathrm{ha}$. The difference here could be explained by ecological factors. This study was carried out in the Guinean savannah while that of Dona in a Sudano-Sahelian zone. Brwon (1997b) reports different amounts in the shrub savannas of Mali (45 t / ha), Senegal (32 t / ha) and Chad (43 t / ha). In the West African savannas, Sawadogo (2011) also recorded contradictory results. Through their effects on plant biomass, fires consume part of the plant biomass which ends up in the atmosphere in its harmful form of greenhouse gases. Poilecot and Loua (2009) evaluated the biomass losses during the passage of fires between 0 and $12 \mathrm{t} / \mathrm{ha}$ in the Guinean savannas. Also, the biomass loss rates from the work of Toriyama et al. (2014) in Indonesia after ten years of treatment, fires resulted in a loss of productivity of combustible biomass in the order of $26.2 \%$ to $32.3 \%$.

Studies conducted in Kenya (Kamau and Medley, 2014) concluded that fires weaken the productivity and availability of fuel biomass and plant resources at loss 
rates greater than $10 \%$. Kauffman et al. (2003) estimated between 89 and $92 \%$ the share of biomass losses due to uncontrolled fires in tropical dry forests and note that in the long term, the successive losses of biomass due to intense fires affect the entire primary productivity potential of the ecosystem. These results show that the productivity and viability of the high Guinean savannas of Adamawa are dependent on their protection against fires. Securing the shrub and grass layer against fires has a strong influence on the plant production of these plant formations (Adjonou, 2011).

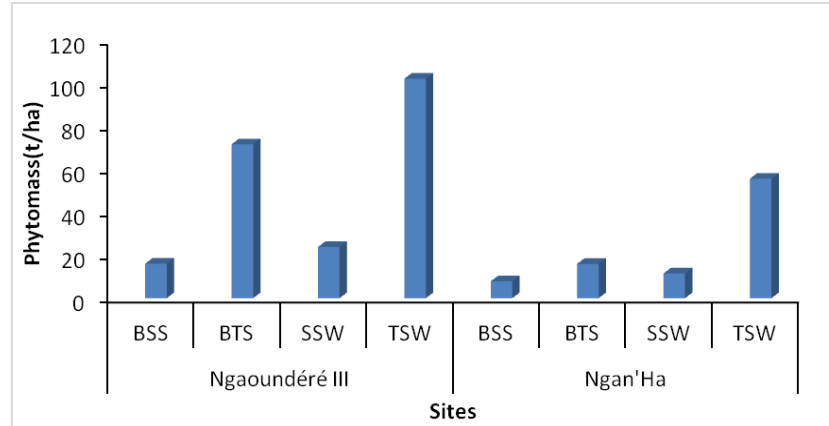

Fig. 5: Aerial phytomass of savannas. BSS: burnt shrub savanna, BTS: burnt tree savanna, SSW: shrub savanna witness, TSW: tree savanna witness.

\section{Hypogeal phytomass of Guinean savannas}

It emerges from Fig. 6 that the control savannas have the greatest quantity of phytomass compared to the burnt savannas. The perfect illustration is given by the controlled tree savannas of Ngaoundéré III (20.70 t / ha). The biomass produced is significant compared to that of burnt savannas (Fig. 6). Statistical analysis indicates a clear difference between the amount of root biomass from plant formations and study sites $(0.001<0.01)$.

The difference between the present results and those of previous work is probably due to human activities (bush fires, tree cutting), the traces of which are clearly identified in these formations the total root phytomass obtained in these plant formations is $96.10 \mathrm{t} / \mathrm{ha}$. This value is low compared to that of the aerial phytomass. This result does not corroborate those obtained by Cesar (1990) in the savannas of the Ivory Coast, showing that the root phytomass is higher than the aerial phytomass. Although the root biomass is less important compared to the above-ground biomass, it plays a non-negligible role in preventing climate change, the environmental consequences of which are very serious (Verstraete et al., 2009).

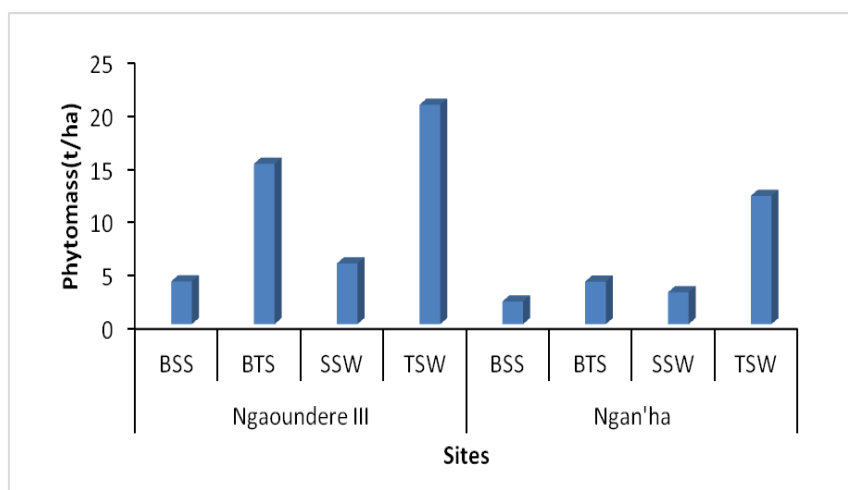

Fig. 6: Hypogeal phytomass of savannahs. BSS: burnt shrub savanna, BTS: burnt tree savanna, SSW: shrub savanna witness, TSW: tree savanna witness.

\section{Carbon stock in the high Guinean savannas}

\section{Above-ground carbon stock}

The quantity of carbon sequestered in the Guinean savannas of Vina varies according to the types of plant formations and the sites. The witness from the tree savannah of Ngaoundéré III shows a higher quantity of carbon (51.11 tC / ha), while it is very low in the burnt shrub savannah (3.92 tC / ha) at Ngan'ha. Statistical analysis reveals a significant difference between the sequestered carbons of the different sites $(0.01<0.05)$.

Our results are higher than those obtained by Dona et al. (2016) in the eastern region of Chad where the aboveground woody carbon stock varies from 11.78 to 15.24 tC / ha. This difference could be due to several parameters such as its grassy nature, therefore less rich in tree species (Monssou et al. (2016). This could also be explained by the quantity of trees (Amougou et al., 2016).

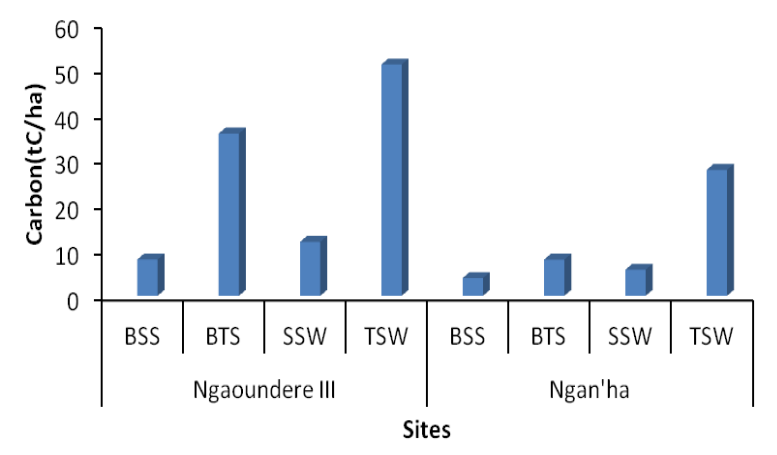

Fig. 7: Above-ground carbon stock of plant formations. BSS: burnt shrub savanna, BTS: burnt tree savanna, SSW: shrub savanna witness, TSW: tree savanna witness. 


\section{Hypogeous carbon stock of the high Guinean savannas}

The stock of root carbon sequestered in the different study sites is higher in the control savannas. Overall, the peak is observed at $10.35 \mathrm{tC} / \mathrm{ha}$ in the savannas of Ngaoundéré III (Fig. 8). The lowest stocks are recorded in the regularly burnt savannas. Along the same lines, Afelu et al. (2016) claim that fire becomes undesirable through its negative impact on plant cover, on the balance and sustainable production of ecosystems. It results in low carbon sequestration. The quantity of carbon in the root phytomass obtained in plant formations is greater than that obtained by Abib (2005) (3.94 tC / ha) in the humid savannas of Ngaounderé. This large difference could be justified by the size of the areas assessed in this study.

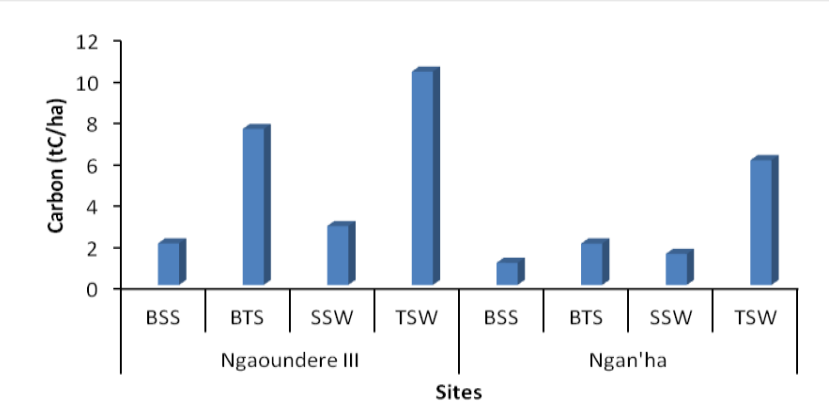

Fig. 8: Hypogeous carbon stock of Guinean savannas. BSS: burnt shrub savanna, BTS: burnt tree savanna, SSW: shrub savanna witness, TSW: tree savanna witness.

\section{Total carbon stock of the high Guinean savannas}

Fig. 9 shows the total carbon value of plant formations. In general, total carbon is important in non-burnt savannas. Its value varies from $7.26 \mathrm{tC} /$ ha in the control of the Ngan'Ha shrub savannah to $61.46 \mathrm{tC} / \mathrm{ha}$ in the control of the Ngaounderé III tree savannah. In the savannas traversed by fires, the carbon values vary from $1.57 \mathrm{tC} /$ ha to $43.41 \mathrm{tC} /$ ha respectively in the burnt shrub savannah and woodland savannah of Ngaoundéré III. There is a significant difference between sites $(0.001<0.01)$ and plant formations $(0.0000<0.001)$. The total quantities of carbon obtained in the Ngaoundéré III site and in the unburned tree savannas are greater than those in the burned tree savannas. The total carbon stock obtained in the high Guinean savannas of La Vina is $177.33 \mathrm{tC} / \mathrm{ha}$. This result is dissimilar to $211.60 \mathrm{tC} / \mathrm{ha}, 325.5 \mathrm{tC} /$ ha and $154.868 \mathrm{tC} / \mathrm{ha}$ obtained respectively in forest zone (Kotto-Same et al. 1997), in Ayos (Silatsa et al., 2015) and in the peri-urban area of Ngaoundéré (Ibrahima and Abib, 2008). These different results confirm the variability of carbon stocks according to ecological zones and plant groups. These authors also report that the carbon stock varies with topography.

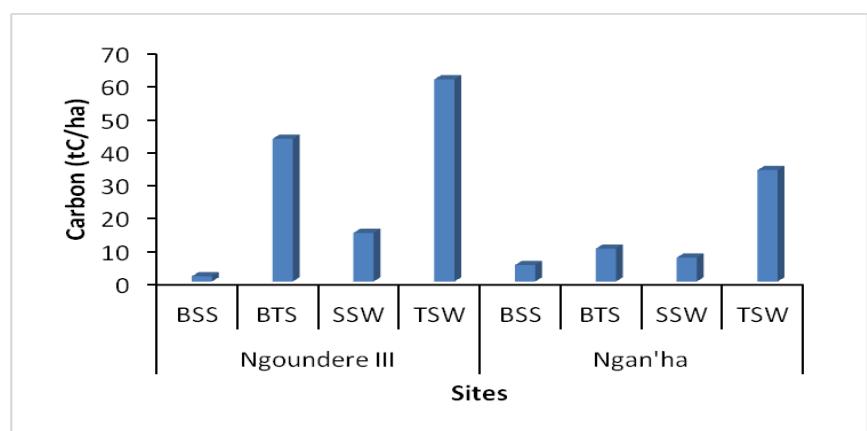

Fig. 9: Total carbon of the Guinean savannas. BSS: burnt shrub savanna, BTS: burnt tree savanna, SSW: shrub savanna witness, TSW: tree savanna witness

\section{Conclusions}

From this study, it emerges that the destruction of property (destruction of fields, burning of houses and granaries), reduction in agricultural yields, increase in heat, disease, disappearance of certain animal species (rabbit, etc.) and especially plants such as Lophira lanceolata, Carissa edulis, Sarcocephallus latifollius are the disadvantages of fires according to the populations. Faced with climate change, local knowledge such as reforestation, the use of organic fertilizers and awareness against bushfires has been developed to reduce their resentment.

A total of 51 species were inventoried, divided into 46 genera and 23 families. The most dominant species are Annona senegalensis, Piliostigma thonningii, Hymenocardia acida. The demographic structure (diameters, heights,) of the savannas follows an "L" shaped distribution. The actions of fires on ligneous plants have a significant impact on the dynamism of the vegetation and its progression towards the climax. Savannahs that have not been set on fire (trees and shrubs) are richer in biodiversity overall compared to those that have been burnt down.

Savannahs that are not burnt produce more biomass than those that are burnt. The perfect illustration is given by the non-burnt tree savannah of Ngaoundéré III with an above-ground and root biomass of $102.23 \mathrm{t} / \mathrm{ha}$ and $20.70 \mathrm{t} /$ ha respectively. Annona senegalensis (1.27 $\mathrm{tC} / \mathrm{ha}$ ) is the species contributing massively to carbon 
sequestration in the high savannas of the Vina. Uncontrolled fires deplete ecosystems with the plant biomass necessary for soil protection and restoration as well as for the needs of human and animal populations. Also, by acting on the availability of plant biomass, fires contribute to the erosion of biodiversity. Indeed, whatever the type of fire and the regime of its prescription, the biomass which burns reinforces the atmospheric pollution by the emission of aerosols and greenhouse gases which negatively impact the availability of the plant resource for the needs of the populations and the balance of ecosystems. Thus, securing or the type of fires on the woody cover of Adamaoua and generally at the national level of Cameroon with the improvement of the populations' knowledge on the dynamics of fires and their impacts on the structure, diversity and plant production, forest ecosystems are desirable. Faced with the challenges of climate change, the importance of scientific research in understanding and controlling vegetation fires is becoming essential for the protection of forest ecosystems, the sustainable management of biodiversity, food security and the fight against poverty.

\section{Conflict of interest statement}

Authors declare that they have no conflict of interest.

\section{Acknowledgement}

The authors of this work are indebted to the populations who collaborated in the household surveys; field guides who facilitated interactions with the different populations. They also extend their gratitude to the anonymous readers for their comments which have improved the quality of the manuscript.

\section{References}

Afelu, B., Fontodji, K., Kokou, K., 2016. Impact des feux sur la biomasse dans les savanes guinéosoudaniennes du Togo. La Revue électr. Sci. Environ., 16(1) : 3-22.

Alalade, O.A., Oladunni, O.A., Akinboye, O.A., Daudu, A.K., Ogunrinde, T.O., 2019. Adaptation to climate change: evidence of coping strategies used by fish farmers in pategi local government area of Kwara state, Nigeria. Int. J. Agric. Environ. Res., 5(3): 2455-6939.

Amougou, J.A., Bembong, E.L.D., Batha, R., Mala, A.W., Ngono, H., 2016. Estimation du stock de carbone dans deux unités de terre en zone de savane du Cameroun. Rev. Géographie, 2: 28-45.

Bane-Ena, W., 2007, Pratiques culturelles exogènes et menace de la biodiversité en Afrique subsaharienne: cas du Togo, Mémoire de DEA, Sociologie, Université de Lomé, 78p.

Basnet, B.M.S., 2009. Rice and Water. In: Our Heritage. pp. 29-31.

Bowman, J.S., Wilson B.A., 1995. Munmarlary revisited: response of north Australian Eucalyptus tetrodonta savanna protected from fire for 20 years. Aust. J. Ecol., 20(4): 526-531.

Brown, S., 1997a. Forests and climate change: Role of forest lands as carbon sinks. Proceeding of XI World forestry Congress, Antalya, Turkey. pp. 1322.

Brown, S., 1997b. Estimating biomass change of tropical forests: a primer. FAO forestry paper, 134, FAO, Rome, Italy. 55p.

Cairns, M.A., Brown, S., Helmer, E.H., Baumgardner, G.A., 1997. Root biomass allocation in the world's upland forests. Oecologia, 111: 1-11.

Convention Cadre des Nations Unies sur les changements Climatiques (CCNUCC), 2015. Préserver le Climat. Guide de la Convention sur les changements climatiques et de Paris; Bonn, Allemagne, $4 p$.

Chave, J., Rejou-Mechain, M., Burquez, A., Chidumayo, E.N., Colgan, M., Delitti, W., Duque, A.J., Welington, D., Fearnside, P.M., Goodman, R., Henry, M., Martínez-Yrízar, A., Mugasha, W., Muller-Landau, H., Mencuccini, M., Nelson, B., Ngomanda, A., Nogueira, E., Ortiz-Malavassi, E., Pélissier, R., Ploton, P., Ryan, C. M., Saldarriaga J.G., Vieilledent, G., 2014. Improved pantropical allometric models to estimate the above ground biomass of tropical forests. Glob. Change Biol., 20: 3177-3190.

Curtis, J.T., McIntosh, R.P., 1950. The interrelations of certain analytic and synthethic phytosociological characters. Ecology, 31: 434-455.

Diop, A.T., 2007. Dynamique écologique et évolution des pratiques dans la zone sylvopastorale du Sénégal: perspectives pour un développement durable, Presse nationales, 190 p. [En ligne] URL : http:/ www.ucad.sn/informations. Consulté le 15 Juillet 2012.

Ducroux, R., Jean, B. P., 2004. L'effet de serre. Réalités, conséquences et solutions, CNRS éditions, Paris, 96p.

GIEC, 2005. Piégeage et stockage du dioxyde de 
carbone. Rapport spécial. 66p.

GIEC, 2007. Bilan 2007 des changements climatiques. Contribution des Groupes de travail I, II et III au quatrième Rapport d'évaluation du Groupe d'experts intergouvernemental sur l'évolution du climat GIEC, Genève, Suisse, 103p.

Ishaya, S. Apochi M.A., Abdullahi Hassa, M., 2018. Climate change perception among geography and biology teaching Gwangwalada area council of the federal capital territory of Nigeria. Ann. Ecol. Environ. Sci. 2(4): 1-11.

Kemeuze, V.A., Mapongmetsem, P.M., Sonwa, D., Fongnzossie. E., Nkongmeneck, B.A., 2015. Plant diversity and carbon stock in sacred groves of semiarid areas of Cameroon: case study of Mandara mountains. Int. J. Environ., 6(2): 308-318.

Koffi, B., J., Grégoire, M., Mahé, G., Lacaux, P., 1995. Remote sensing of bush fire dynamics in Central Africa from 1984 to 1988: analysis in relation to regional vegetation and pluviometric patterns, Atmospheric Res., 39 (1-3): 179-200.

Kotto-Same, J., Woomer P. L., Moukam, A., Zapfack, L., 1997. Carbon dynamic in slash and-burn agriculture and land-use alternaties of the humid forest zone in Cameroon. Agric. Ecosyst. Environ., 65: 245-256.

Kwon, T.-S., Sung-Soo, K., Min, L.C., Seung, J.J., 2013. Changes of butterfly communities after forest fire. J. Asia-Pac. Entomol., 16(4): 361-367.

Lambin, E.F., Turner, B.L., Geist, H.J., Agbola, S.B., Angelsen, A., Bruce, J.W., Coomes, O.T., Dirzo, R., Fischer, G., Folke, C., George, Homewood, P.S., Imbernon, J., Leemans, R., Lin, X., Moran, E.F., Mortimore, M., Ramakrishna, P.S., Richards, J.F., Skanes, H., Steffent, W., Stone, G.D., Svedin, U., Veldkamp, T.A., Vogel, C., Xu, J., 2001. The causes of land-use and land-cover change: moving beyond the myths. Global Environ. Change, 11: 261-269.

Loreau, M., 2001. Biodiversity loss and the maintenance of our life-support system. Proceedings of tire global change open science conference, Amsterdam, the Netherlands. pp. 169173.

Mapongmetsem, P. M., Hamawa, Y., Djeumene, P., Maissele, D., Kossebe, C.F., Ndoum, J.F., Nduryang, F., Bebbe, D., Bouba, S., Wouldata, L., Zigro, Barbi, M., 2008. Valorisation des plantes alimentaires et sauvages dans les savanes soudano guinéennes du Cameroun, In: Kapseu, C., Mbofung, C.M., Amvam Zollo, P.H.(Eds), Développement de l'agro-industrie et création des richesses (Ngaoundéré, Cameroun) Actes, Conférences internationale du 9-11 juillet 2009, Ngaoundéré, pp. 50-61.

Mapongmetsem, P. M., Tchotsoua, M., Duguma, B., Nkongmeneck, B.A., 2000. Some strategies for reversing Adamawa highlands degradation. Rev. Ngaoundéré-Anthropos, 5: 107-126.

Mapongmetsem, P. M., Nkongmeneck, B. A., Rongoumi, G., Dongock Nguemo, D., Dongmo, B., 2011. Impact des systèmes d'utilisation des terres sur la conservation de Vitellaria paradoxa dans les savanes soudano-guinéennes. Inter. J. Environ. Stud., 68(6): 851-872.

Monnier, Y., 1973. La problématique des savanes en Afrique de l'Ouest. Compte rendu du colloque du programme biologique international sur les milieux herbacés d'Afrique. Ann. Univ. Abidjan, 6(2): 3577.

Monssou, E.O., Vroh, B.T., Goné, B.Z., Adou, Y.C.Y., N'Guessan, K.E., 2016. Evaluation de la diversité et estimation de la biomasse aérienne des arbres du Jardin Botanique de Bingerville (District d'Abidjan, Côte d'Ivoire). Eur. Scient. J., 12(6): 1857-7881.

Pielou, E. C., 1966. The measurement of diversity in different types of biological collections. J. Theor. Biol., 13(2): 131-144.

Rippstein, G., Boudet, G., 1977. Expérimentation sur parcours de savanes tropicales humides. Com. $1^{\mathrm{er}}$ Colloque International sur l'élevage bovin des zones tropicales. Bouaké. 15p.

Rippstein, G., 1985. Etude sur la végétation de l'Adamaoua: évolution, conservation, régénération et amélioration d'un écosystème pâture au Cameroun. Etudes et Synthèse de l'Inst. Elev. Med. Vet. Pays Trap., 33(3): 229-337.

Sawadogo L., 2011. L'influence des feux sur la biodiversité des savanes ouest africaines, Atlas de la Biodiversité de l'Afrique de l'Ouest, Côte d'Ivoire, Tome III, BIOTA, pp. 72-73.

Silatsa, T.F.B., Yemefack, M., Dameni, H., 2015. Variabilité des stocks de carbone en zone forestière du Cameroun: Approche évaluative dans le paysage agricole itinérant de la commune d'Ayos. Editions Universitaires Européennes, 110p.

Tchobsala, Mbolo, M., 2013. Characterization and impact of wood logging on plant formations in Ngaoundéré District, Adamawa Region, Cameroon. J. Ecol. Natural Environ., 5(10) : 265-277.

Tchobsala, 2011. Influence des coupes de bois sur la dynamique de la végétation naturelle de la Zone 
périurbaine de Ngaoundéré (Adamaoua). Thèse de Doctorat/Ph.D/Université de Yaoundé I.184p.

Tchobsala, Mbolo, M., Souare, K., 2014. Impact of wood logging on the phytomass and carbon sequestration in the guinea savanna of Ngaoundéré, Adamaoua Region, Cameroon. Global Adv. Res. J.
Environ. Sci. Toxicol., 3(2): 2315-5140.

Vieira, D.C.S., Fernandez, C., Vega, J.A, Keizer, J., 2015. Does soil burn severity affect the post-fire runoff and erosion response? A review based on meta-analysis of field rainfall simulation data. J. Hydrol., 523 (15): 452-464.

\section{How to cite this article:}

Pamboundem, N. A., Tchobsala, Oumarou, Z., Dona, A., Mapongmetsem, P. M., 2021. The influence of periodic fires on the high Guinean savannas and the carbon stock in Cameroon. Int. J. Curr. Res. Biosci. Plant Biol., 8(11): 920. doi: https://doi.org/10.20546/ijcrbp.2021.811.002 